\title{
General Definition of the Concept Sports
}

\author{
Vasil Sutula* \\ Professor, Doctor of Education, Kharkiv State Academy of Physical Culture, Europe
}

Submission: July 03, 2018; Published: July 12, 2018

*Corresponding author: Vasil Sutula, Professor, Doctor of Education, Kharkiv State Academy of Physical Culture, Europe, Tel: 067-70-50-491;

Email: vsutula@rambler.ru

Abstract

The purpose of the study is to uncover modern ideas about the essence of the concept of "sport".

Methods of Research: Include an analysis of special literature, which covers various aspects of the development of the field of human activities associated with the use of physical exercises.

The Results of the Analysis: Shows that sport as a special socio-cultural phenomenon is a historically determined activity of people connected with the use of physical exercises, which is aimed at preparation and participation in competitions, as well as individual and socially significant results of such activity.

Keywords: Physical Culture; Sport; Theory; Concept; Needs

\section{Problem Statement, Analysis of Recent Research- es and Publications}

The results of the analysis of the special literature, in which the concept sport is used and analyzed, testify to the existence of certain differences in its definition. The existing differences are reflected in the regulatory legal documents regulating the activities of people in the field of sports and scientific works of specialists from different countries. For example, in the report of the United Nations Inter-Agency Task Force on Sport for Development and Peace [1] it is noted that the term sport covers all forms of physical activity that promote good physical fitness, mental well-being and social interaction. It includes games, entertainment, recreational or competitive sporting events, as well as sports and traditional games. The "Sports Charter of Europe" [2], adopted in 1992 at the Ministerial Conference on Sport of the States of Europe, gives the following definition of sport: "sport means all forms of physical activity which, through random or organized participation, are directed towards the expression or improvement of physical and mental well-being, formation of social relations or achievement of results in competitions of all levels".

The problem of the correct definition of the concept of "sport" is actively discussed in the scientific community, including specialists from post-Soviet countries. Thus, L Matveev [3], revealing the nature of contemporary sport, offers two of its definitions "in the narrow sense and in the broadest sense." In his opinion, "sport in the narrow sense is legitimate to call only the actual competition activity", and in the broad sense (but not overly extended) the concept" sport "covers the actual competitive activity, the process of preparation for achievements in it, as well as specific interspecific relations and behavioral norms arising on the basis of this activity".

This problem is widely covered in English-language scientific practice. Thus, K Shillinh [4] notes that the definition of "sport" has historically changed, but now it is used to describe those activities and games that have become a competitive race between teams or individuals and the public received the highest rating. The complexity of the correct definition of "sport" and pay attention D Koukli, E Danninh [5] noting that the attempt to introduce a comprehensive definition of the term "sport" that runs in any cultural environment proved illusory. In their opinion, the only definition for such an institution is comparable to the concept of "religion".

On the existing contradictory definition of the concept of "sport" pay attention and German specialists. Thus, M Frentsel [6] at work "policy in Darmstadt" vidmichav that the concept of "sport" covers various types of physical activity that participants show event held on the principle of fair rules and includes a special sports ethics. H Sorzho [7] to work "Asceticism and consumption" draws attention to the fact that the exact definition of sport is controversial and so far it has not been clearly defined. The same position is K Dreer [8], who in his thesis stated that so far the existing wording of the concept of "Sports" not found universal acceptance. 
The raised problem is actively discussed also in the environment of the French scientific community. Thus, O Naarier [9] states that at present an active search work is underway to define the concept of "sport", which should lead to a refinement of this complicated term. According to his data, nobody was able to offer his consensus definition. T Terret [10] in the editorial of the journal "Kinds of Sports" observes that the question of determining the essence of sport, inspired by academic discourses of the 1960s and 1970s, will never be fully resolved. P Bucha and K Swobri [11], paying attention to the complexity of the definition of "sport", note that at present there are more than 200 encyclopedic definitions.

The above review of definitions of the concept of "sport" used in normative legal documents, as well as the analysis of the results of scientific inquiries carried out by specialists from different countries on the problem of forming modern ideas about the socio-cultural nature of sport, are not exhaustive. However, they indicate the existence of a clearly expressed contradiction. On the one hand, there are a number of definitions of the concept of "sport", which differ in form but have similar substantive-structural basis and on the other hand, it is stated that it is impossible to introduce a "consensus" definition of this concept. The latter provision, taking into account its scientific and practical significance, requires a separate and more thorough analysis that goes beyond the scope of this article. The main results of this analysis are presented in a separate article [12].

\section{Conclusion}

a) The review of definitions of the concept of "sport" used in normative documents, as well as the results of the analysis of scientific researches carried out by specialists from different countries on the problem of forming modern ideas about the socio-cultural nature of sport, have been carried out, indicating the existence of a clearly expressed contradiction. On the one hand, there are a number of definitions of the concept of "sport", which differ in form but have similar substantive-structural basis and on the other hand it is stated that it is impossible to introduce a "consensus" definition of this concept. b) The clarifications made to the operational and resultant components in the wording of the concept of "sport", which are used in scientific practice, allowed to formulate the following generalization (consensus) definition of the concept of "sport". Sport as a special sociocultural phenomenon, is a historically determined activity of people connected with the use of physical exercises, which is aimed at preparing and participating in a specially organized system of competitions, as well as individual and socially significant results of such activity.

\section{References}

1. Le Sport Au (2003) Service Du Developpement Et De La Paix: A Versa La Realisation Desensitie two millennia to develop. Rapport deletudes deleconomie Unies surle sport and servise dudéveloppement et de la paix, p. 43

2. lib.sportedu.ru/GetText.idc?TxtID=1542.

3. Matveev LP (2005) The general theory of sport and its applied aspects. $4^{\text {th }}$ Correction and add SPb Publishing House Lan, pp. 384.

4. Shilling C (2005) The Body in Culture, Technology and Society. SAGE Publications, pp. 101.

5. Coakley J, Dunning E (2000) The Handbook of Sports Studies. SAGE Publications, pp. 570.

6. Martin Frenzel (2005) Politik für Darmstadt, Peter Benz and seine Zeit Liebig, pp. 535.

7. Gabriele Sorgo (2002) Askese and Konsum. Turia + Kant, pp. 272.

8. Christian Dreher (2005) Staatsziele im Bundesstaat am Beispiel des Sports. Inaugural dissertation is available at the Doktorwurde. Hohen Rechtswisstnschaftlichcu Fakultat der Universitat zu Koln, pp. 257.

9. Olivier Naria (2008) Géographie dusporàla Reunion. Cultures sporditions and theoristoires, pp. 430.

10. Thierry Terret Le (2006) Genre du sport. CLIO Histoire Femmes et Societes, p. 7.

11. Patrick Bouchet, Claude Sobry (2005) Management et marketing du sport: du local au global. Sport et seiences sociales. Presses Universitaires Sptentrion Paris, p. 19.

12. Vasyl Sutula (2018) The generalization of the definition of the concept of sport as one of the basic constructs of the theory of physical culture and the theory of sports. Slobozhansky scientific and sports newsletter 1(64): 89-97.

Your next submission with Juniper Publishers will reach you the below assets

- Quality Editorial service

- Swift Peer Review

- Reprints availability

- E-prints Service

- Manuscript Podcast for convenient understanding

- Global attainment for your research

- Manuscript accessibility in different formats ( Pdf, E-pub, Full Text, Audio)

- Unceasing customer service

Track the below URL for one-step submission https://juniperpublishers.com/online-submission.php 